\section{Occurrence of Peach Tree Short Life on a Field Site with No History of Peach Production}

\author{
A.P. Nyczepir ${ }^{1}$ and W.R. Okie ${ }^{2}$ \\ U.S. Department of Agriculture, Agricultural Research Service, Southeastern \\ Fruit and Tree Nut Research Laboratory, 111 Dunbar Road, Byron, GA 31008
}

Additional index words. Criconemella xenoplax, Prunus persica

Peach tree short life (PTSL) usually is associated with poor management practices and the continuous presence of the ring nematode [Criconemella xenoplax (Raski) Luc \& Raski $=$ Mesocriconemaxenoplax (Raski)Loof $\&$ de Grisse]. Bacterial canker (Pseudomonas syringae pv. syringae van Hall), cold injury, or both are responsible for the sudden springtime collapse of peach trees associated with PTSL in the southeastern United States (Brittain and Miller, 1978). However, C. xenoplax (Cx) clearly has been identified as the primary biotic factor essential for PTSL to occur (Nyczepir, 1990). Although generally associated with old orchard sites, PTSL can be induced in virgin peach soil in field microplots by inoculation with ring nematode (Nyczepir, 1990). Our objective was to determine if PTSL could occur on land not planted with peaches for $\geq 75$ years.

The field site was a loamy sand $(86 \%$ sand, $10 \%$ silt, $4 \%$ clay; $1.54 \%$ organic matter) located at the Southeastern Fruit and Tree Nut Research Laboratory, Byron, Ga. The site, recently cleared of $\approx 75$-year-old pecan trees, had no known history of peach production. Soil $\mathrm{pH}$ was 6.0 , so preplant liming was not required. Preplant nematode soil samples revealed no Cx in July 1985 . Twenty-four rooted cuttings of Nemaguard were planted at $6 \times 6 \mathrm{~m}$ in Dec. 1985. Each of 12 cuttings had been inoculated with 10,000 adult and juvenile $\mathrm{Cx}$ per $3700 \mathrm{~cm}^{3}$ soil in Apr. 1985, while the remaining 12 cuttings received nematode-free water extract from the culture medium and served as controls (Nyczepir, 1990). Each nematode-inoculated tree also received 16,000 $\mathrm{Cx}$ in the planting hole. Treatments were replicated 12 times and arranged in a randomized complete-block design. Trees were cultured as recommended by the Georgia Cooperative Extension Service. Nematode populations were monitored beneath the canopy of each tree in

Received for publication 8 July 1995. Accepted for publication 5 Oct. 1995. The cost of publishing this paper was defrayed in part by the payment of page charges. Under postal regulations, this paper therefore must be hereby marked advertisement solely to indicate this fact.

${ }^{1}$ Research Nematologist.

${ }^{2}$ Research Horticulturist.
Dec. 1986, Dec. 1987, Feb. 1989, and Dec. 1989 (Nyczepir, 1990). Trees were pruned annually in Dec. of 1986, 1987, and 1989 to encourage PTSL.

Neither tree death nor typical PTSL symptoms occurred in the initial planting, although conditions, including the presence of $\mathrm{Cx}$, appeared suitable for disease development. Nematode density increased dramatically in the inoculated plots, with a 1-year lag in increase under control trees (Table 1). By 1987, there was no significant difference between treatments. The presence of a native $\mathrm{Cx}$ population not detected in the preplant sampling, movement of soil via machinery, or both might explain the nematodes present in the control treatment. Although we no longer had a nematode-free control treatment, we continued the orchard-generation time and incidence of PTSL. When no trees died in the first 6 years, which is the period most likely for PTSL to occur, all trees were removed in Sept. 1991.

A second planting of commercial varieties on Nemaguard rootstock was made in Feb. 1992, with each tree occupying the same location as a previous tree. All trees were December-pruned. Because no trees in the second planting were in nematode-free soil, a composite sample consisting of six soil cores (one per tree) from each of four rows of trees was obtained. Mean population density of $\mathrm{Cx}$ per $100 \mathrm{~cm}^{3}$ soil was 293 and 78 in Mar. and Dec. 1993, respectively, and 135 and 175 in Mar. and Dec. 1994, respectively. In the southeastern United States, PTSL symptoms are accompanied by the continuous presence of $\mathrm{Cx}$. A nematicide treatment is recommended in South Carolina if $\mathrm{Cx}$ populations exceed 50 nematodes $/ 100 \mathrm{~cm}^{3}$ soil. study to determine the relationship between

${ }^{2}$ Preplant Cx population density.
In Apr. 1993, three trees developed typical PTSL symptoms and died. Four trees developed symptoms in Apr. 1994 and two in May 1995 , and they died. Tree death in the second orchard was $37 \%$ after three growing seasons.

No PTSL occurred in the first planting despite the presence of $\mathrm{Cx}$. Possibly, climatic conditions were unsuitable, although PTSL was observed elsewhere in those years. The rapid appearance of PTSL symptoms and tree death in our second planting substantiates a common pattern. Sharpe et al. (1989) noted that the severity of PTSL in a commercial orchard infested with $\mathrm{Cx}$ increased, and thus orchard lifespan decreased with each successive peach planting. Although the estimated population density of $\mathrm{Cx}$ around 1-year-old trees in the first planting (Dec. 1986) was higher than at a comparable time in the second planting (Mar. 1993), PTSL was absent in 1986. Uneven root distribution under young trees and the cyclic interaction of the nematode and root that is obscured by infrequent soil sampling may explain the differences in $\mathrm{Cx}$ population detected. In addition, placing new trees into soil recently planted with peach would expose the roots to rhizosphere microflora and microfauna very different from planting into virgin soil. The $\mathrm{Cx}$ population also would be better established and more pervasive in the root zone after 5 years compared to the nematode population in the first planting, which was initially confined to a smaller area. Tree roots in the first planting probably could extend into noninfested soil, thus minimizing the parasitic impact by Cx. Rapid parasitism of new roots, as would occur in the second planting, may be a critical factor to the incidence of PTSL and needs to be investigated further. A technique that allows a researcher to create a PTSL site in 1 or 2 years would be useful for evaluating Prunus for resistance to this nematode-related disease complex.

\section{Literature Cited}

Brittain, J.A. and R.W. Miller. 1978. Managing peach tree short life in the southeast. Clemson Univ. Coop. Agr. Ext. Serv. Circ. 585, Clemson, S.C.

Nyczepir, A.P. 1990. Influence of Criconemella xenoplax and pruning time on short life of peach trees. J. Nematol. 22:97-100.

Sharpe, R.R., C.C. Reilly, A.P. Nyczepir, and W.R. Okie. 1989. Establishment of peach in a replant site as affected by soil fumigation, rootstock, and pruning date. Plant Dis. 73:412-415.

Table 1. Soil population density (1985 to 1989) of Criconemellaxenoplax (Cx) on Nemaguard peach planted in Dec. 1985 on a site not recently planted with peaches $(n=12)$.

\begin{tabular}{lccccc}
\hline \hline & \multicolumn{5}{c}{ No. nematodes/100 $\mathrm{cm}^{3}$ soil } \\
\cline { 2 - 6 } Treatment & July $1985^{z}$ & Dec. 1986 & Dec. 1987 & Feb. 1988 & Dec. 1989 \\
\hline Cx $^{y}$ & 0 & $583^{* *}$ & $442^{\text {ss }}$ & $490^{\text {ss }}$ & $126^{*}$ \\
Control & 0 & 119 & 417 & 634 & 405 \\
\hline
\end{tabular}

${ }^{y}$ Each tree inoculated with a total of 26,000 juvenile and adult $\mathrm{Cx}$.

Ns, ,***Nonsignificant or significant at $P \leq 0.05$ or 0.01 , respectively, according to $\mathrm{F}$ test. Nematode data were transformed $\left[\log _{10}(\mathrm{x}+1)\right]$, but nontransformed data are presented. 